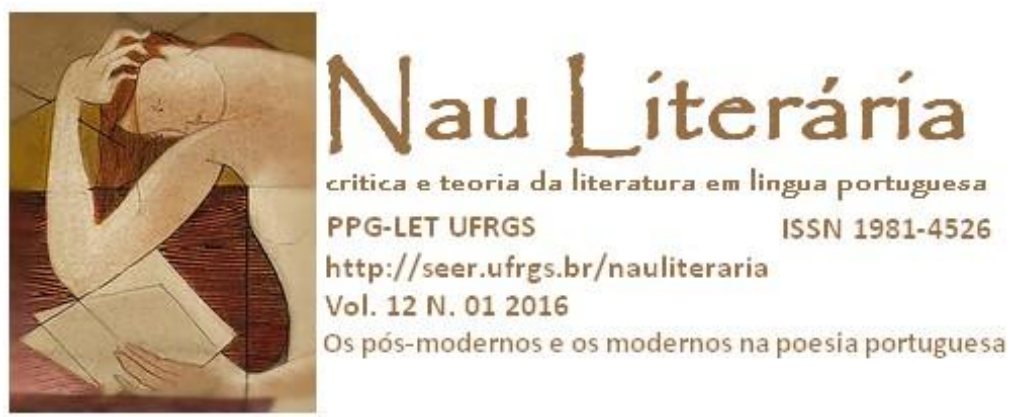

\title{
POESIA, TEMPO E HISTÓRIA: As elegias de Fernando Pinto do Amaral e a poesia historicista de Milton Torres
}

\section{POETRY, TIME AND HISTORY: Fernando Pinto do Amaral's elegies and Milton Torres' historicist poetry}

Laurene Veras ${ }^{1}$

RESUMO: O artigo faz uma análise das obras Dez elegias para o fim do milênio, do português Fernando Pinto do Amaral e $O$ fim das terras do brasileiro Milton Torres sob uma perspectiva crítica da poesia enquanto forma literária inserida no tempo e na história. São utilizados como fundamentação teórica os postulados estéticos de Hegel e Octavio Paz.

PALAVRAS-CHAVE: Poesia; Tempo; História; Brasil; Europa.

ABSTRACT: The article analyzes the works Dez elegias para o fim do milênio, by the Portuguese poet Fernando Pinto do Amaral and $O$ fim das terras by the Brazilian poet Milton Torres in a critical perspective of poetry as a literary form inserted in time and history. As theoretical postulates are been used the aesthetics ideas of Hegel and Octavio Paz.

KEYWORDS: Poetry; Time; History; Brasil; Europe.

A poesia lírica está em oposição à poesia épica. Volta-se para a subjetividade e é uma sua derivação. De caráter particular, a poesia lírica é expressa pelo sujeito através de sentimentos que leem o mundo. O texto poético pode, neste sentido, estar imbuído das mais distintas impressões, versando tanto sobre assuntos cotidianos quanto metafísicos, desde que estes passem pelo crivo da interioridade do sujeito expressivo. A este sujeito chamamos de eu lírico.

\footnotetext{
${ }^{1}$ Graduada em Filosofia e Mestre em Letras pela UFRGS; Professora no Colégio Madalena Sofia e Rede Estadual do Paraná. E-mail: doloresdavi@gmail.com
} 
Na cultura ocidental, a poesia lírica se origina na Grécia Antiga e atravessa os séculos passando por diversas escolas poéticas, obedecendo a suas respectivas métricas e determinadas características de especificidades periféricas, guardando sempre o mesmo caráter de subjetividade inerente à sua natureza. Assim, um poema lírico pode tanto se debruçar sobre temas da sensação imediata quanto por sobre sentimentos e impressões voltados para a abstração, na medida em que o assunto do poema seja direcionado desde a percepção do sujeito sobre as questões que o provocam.

Em dois textos líricos, como Dez elegias para o fim do milênio, do português Fernando Pinto do Amaral, e No fim das terras, do brasileiro Milton Torres, o que nos chama a atenção são os títulos de ambos, os quais trazem à tona uma temática escatológica. No sentido filosófico, a palavra "fim", presente nas duas obras, remete ao final da história da humanidade, portanto, o nome escolhido por Amaral indica que o livro se refere ao fim do tempo no qual ele está inserido, enquanto o título de Torres situa o leitor em direção ao fim de um âmbito espacial em princípio indeterminado.

Esses títulos encontram-se em diálogo na medida em que o fim das terras pode ser interpretado como o fim das coisas todas, se pensarmos que o fim do mundo pode ser compreendido tanto como o findar da história quanto como a extinção do espaço tal qual o percebemos. Além disso, os dois livros em questão permanecem numa relação de reciprocidade enquanto um se dirige imediatamente ao tempo e outro ao espaço, se lembrarmos que Hegel situa a poesia em uma circunstância espaço-temporal quando afirma que "Se definirmos as palavras como simples meios da designação das representações, nem por isso deixa de ser verdade que a poesia introduz nesses meios os elementos do tempo e o do som"(HEGEL, 1964, p.435). Ora, o som depende de uma dimensão espacial para se propagar, logo, se a poesia introduz a palavra nos ambientes do tempo e do som, temos que a poesia de fato ocorre em um âmbito de tempo e espaço.

Publicado em 2000, Dez elegias para o fim do milênio percorre as paisagens de dez lugares escolhidos pelo eu lírico, descrevendo espaços e impressões quase sempre melancólicas de cidades, lugares e vilarejos. Apesar da ocorrência de localidades como o castelo de Muzot ou do estreito de Bósforo, por exemplo - que a despeito de trazerem a marca de uma localização geográfica configuram-se na obra mais como espaço literário, imaginado e simbólico - predomina no livro de Amaral o espaço urbano. Deste modo, o 
canto de Amaral divide-se em dez poemas melancólicos, porém agitados pelo burburinho incessante da urbe. São elegias por caracterizarem-se pelo tom fúnebre, constituindo-se o livro em um conjunto de adeuses que se intercalam nas cidades e lugares pelos quais transita o eu lírico, o qual se despede de um tempo que aos poucos vai se encaminhando para o seu fim.

A preocupação com o tempo se estende para além do título, a partir da epígrafe. Tradutor de toda a poesia de Jorge Luis Borges é mesmo em espanhol que Amaral escolhe abrir sua obra, nas palavras do mestre dos labirintos. No poema-arauto de Borges, o argentino alerta para os cuidados que se há de tomar com a sucessão do tempo, que é figurada na alternância das noites e dias, a qual não passa de ilusão na medida em que o presente fugidio é também a prisão da existência humana no tempo:

Entre el alba y la noche hay un abismo
de agonias, de luces, de cuidados;
el rostro que se mira em los gastados
espejos de la noche no es lo mismo.
El hoy fugaz es tenue y es eterno;
otro Cielo no esperes, ni outro Inferno.

\section{JORGE LUIS BORGES}

Em se tratando de elegias, um dos recursos mais marcantes dos poemas de Amaral é o uso contínuo de palavras de mesmo campo conceitual, no caso, vocábulos e expressões que remetem à já citada melancolia e tristeza expressas na obra. Assim sendo, expressões como "céu tão baço", "horas fatigadas", "sensações de um dia exausto" sucedem-se em um desfile de quadros que figuram um eu lírico deprimido, a caminhar entre o cair da tarde e o amanhecer em uma metrópole plena de personagens indefinidas e solitárias que habitam a Elegia de Lisboa. Primeira poesia de Dez elegias para o fim do milênio, o autor escolheu como ponto de partida sua cidade natal.

Originalmente caracterizada por uma métrica específica, a do dístico elegíaco, na modernidade a elegia não obedece a um metro determinado, mas antes é reconhecida pela temática melancólica. Portanto, também Amaral abre mão da métrica original para fazer uso predominantemente de versos decassílabos e brancos.

A intertextualidade é uma notória assinatura nas Dez elegias de Amaral. Na poesia que abre o livro, o primeiro verso é uma citação de Cesário Verde: "Nas nossas ruas, ao 
anoitecer", de $O$ sentimento de um ocidental, e torna-se o ponto de partida para a jornada noite adentro pelas vielas de Lisboa. Logo no segundo poema, Elegia de Muzot, o eu lírico dialoga a partir do título com Rilke, para no primeiro verso homenagear simultaneamente a este e a Yvette Centeno, conterrânea de Amaral, que tomou emprestado dos versos de Rilke o título de uma de suas histórias, Quem, se eu gritar, verso também escolhido por Amaral para iniciar essa segunda elegia.

A intertextualidade presente no poema de Amaral desvela um eu lírico muito à vontade no fim do milênio cantado por ele, pois alterna a citação tanto de autores portugueses - Cesário Verde, Yvette Centeno, António Nobre, Sá Carneiro, Pessoa - quanto escritores de outras nacionalidades - Rilke, Milton, Byron. Além da nacionalidade heterogênea dos escritores citados, é perceptível a mistura de escolas e épocas literárias. O eu fragmentado do sujeito pós-moderno busca a unidade da poesia nas diversas vozes líricas que povoam seu repertório poético.

Historicamente, Fernando Pinto do Amaral situa enfaticamente o eu lírico das dez elegias no fim do milênio cantado pelas mesmas: trata-se de uma voz poética plural, descentralizada e caleidoscópica. Cidadão do mundo, Amaral recorre a figuras que representam o século moribundo a partir de várias referências culturais, citando, por exemplo, em Elegia de Viena, desde Beethoven, passando por Romy Schneider e sua duplamente célebre Sissi e chegando até Freud.

O cosmopolita eu lírico das dez elegias viaja por uma Europa crepuscular, a qual se despede do fim do milênio imersa numa melancolia de inúmeras identidades nacionais e culturais, passeando por Portugal e visitando Suíças, Espanhas e Áustrias, indo despedir-se nos portões do oriente, na Elegia do Bósforo, sem jamais pisar nas Américas. Na última poesia do livro o eu lírico parece querer dizer que talvez o canto fúnebre pelo fim do milênio não lamente apenas o fim de uma era, mas também o mapa daquela que foi ao mesmo tempo berço da nossa cultura e cadafalso de inesquecível barbárie, que no tempo que se anuncia ecoará nos "remorsos de Deus depois do mundo.":

$$
\begin{aligned}
& {[\ldots]} \\
& \text { O vento sopra, o olhar foge, a mágoa }
\end{aligned}
$$


já deixou de ser mágoa sob os gestos de um anjo que emigrou da sua órbita para nos proteger. A melodia de outubro dissipou o labirinto das vozes respiradas noutros séculos entre o fumo da morte. A própria alma recomeçou a arder, tão provisória como esta quase-noite que celebra um lugar regrassando às mais alheias imagens do abismo que nos salva: uma frase não dita por ninguém, os remorsos de Deus depois do mundo.

Enquanto Fernando Pinto do Amaral escolheu como pano de fundo de suas elegias as paisagens europeias, Milton Torres, com a obra No fim das terras (2004), constrói uma trajetória de poesias que viajam pela história do Brasil. Se a poesia se dá tanto no tempo quanto no espaço, enquanto o poema de Amaral se debruça mais detidamente no âmbito espacial europeu, Torres também passeia por diversas geografias brasileiras, entretanto, o foco do poema se concentra no tempo histórico, mais especificamente em uma cronologia historiográfica que avança num sentido crescente, desde os primórdios do Brasil colonial. A temática historicista é a tônica do livro de Torres, e neste sentido $O$ fim das terras dialoga com a epígrafe borgiana de Amaral, a qual também vai ao encontro do que afirma Otávio Paz:

El tiempo del poeta: vivir al día; y vivirlo, simultáneamente, de dos maneras contradictorias: como si fuese inacabable y como si fuese acabar ahora mismo. Así, la imaginación no puede proponerse sino recuperar y exaltar descubrir y proyectar - la vida concreta de hoy. Lo primero, el descubrir, designa a la experiencia poética; lo segundo, la proyección, se refiere al poema propiamente dicho [...] (PAZ, 2003, p.264)

Poema que abre o livro, Clivagem sugere uma argumentação em latim que se encerra com três versos em português, nos quais fica claro que o poema trata de uma transação comercial para compra de escravos negros. Não por acaso, o título do poema mostra que aqui se inicia uma jornada que será marcada por distinções de classes.

No rumo da primeira poesia, o eu lírico prossegue descrevendo santos de procissão articulados de tradição medieval em Santo de Roca. Em seguida descreve o trabalho escravo, para na poesia seguinte fazer referência ao General Schömberg, militar alemão que residira em Portugal no século XV com o fim de ensinar as artes da guerra. As duas poesias que se 
sucedem versam sobre as guerras jesuíticas, com uma clara referência ao herói indígena Sepé Tiaraju.

Numa leitura descomprometida com a unidade da obra, esta sequência poderia parecer aleatória, no entanto basta nos debruçarmos sobre os fatos históricos para que fique perceptível o encadeamento dos temas abordados. Sendo assim, logo os primeiros seis poemas se revelam como capítulos de uma história que está sendo recontada, cada qual podendo ser identificado pelas seguintes balizas, respectivamente: Brasil colonial, religião, escravidão, ação militar, guerras jesuíticas e o herói. Com os seis poemas de abertura Torres constrói uma elipse que se inicia nos estamentos sociais primordiais do Brasil e se fecha com o mito, ou seja, o autor percorre a clássica trajetória de formação da memória de um povo que começa com uma narrativa factual e vai até a constituição da narrativa simbólica.

De metro livre, as poesias de Fim das terras alternam-se entre diversos idiomas, como o latim, o espanhol, o português, e posteriormente, de acordo com a entrada de outras personagens na história do Brasil, o inglês. Enquanto gradativamente reconstitui a formação da identidade brasileira através da amostragem de suas etnias fundadoras, o eu lírico se permite ao mesmo tempo utilizar-se dos idiomas falados pelos povos que estão sendo caracterizados.

O caráter subjetivo da poesia lírica faz com que a história contada por Torres seja uma história não isenta de comprometimento com o fato, mas, mais que isto, com o fato revisitado pela percepção do eu lírico que o percebe:

Encontramos na poesia épica certos gêneros que se aproximam do tom lírico; também na poesia lírica, por seu turno, encontraremos por seu tema um acontecimento épico, pelo conteúdo e caráter exterior, e apresentado sob uma forma igualmente épica: cantos heroicos, baladas, romances etc. fazem parte desta categoria. A forma de tal conjunto é então, por um lado, a de uma narrativa, posto que relata o curso de uma situação, de um acontecimento, a mudança brusca nos destinos de uma nação etc. Mas, por outro lado, o tom fundamental permanece essencialmente lírico, porque trata acima de tudo não da descrição ou da pintura impassível de um acontecimento real, mas da expressão do modo de conceber e de sentir, do estado de alma alegre ou melancólico, corajoso ou deprimido do poeta e, além disso, porque a ação para a qual a obra lírica foi escrita é também de natureza lírica.[...]Se, pois, o tema é épico, o estilo ou modo do seu tratamento é lírico. (HEGEL, p.515) 
Prosseguindo na cronologia ascendente da obra, Torres retrata em sua lírica o ciclo do ouro e as Minas Gerais, a Inconfidência Mineira e algumas das célebres protagonistas da revolução malograda, como Marília de Dirceu e Chica da Silva, esta última cantada em Madrigal a uma negra:

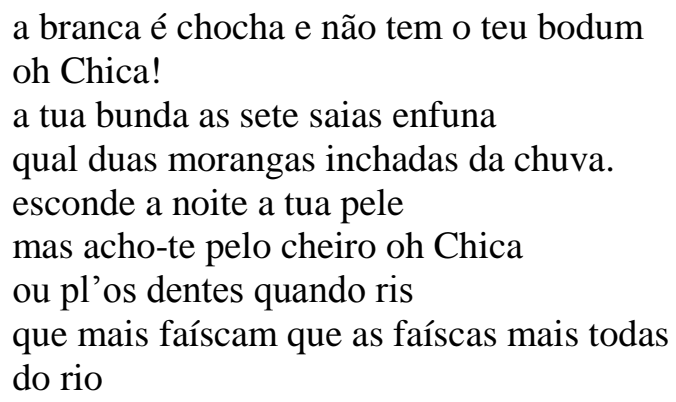

De admirável capacidade de síntese, as poesias de Torres são padrões que marcam a soberania dos acontecimentos históricos no território da memória cultural brasileira. Deste modo, a voz que canta a beleza e o magnetismo de Chica da Silva é a voz do tratador João Fernandez, que mesmo implícito nesse poema se faz presente na declaração do seu amor pela ex-escrava através dos indícios da intimidade que só pode ser partilhada por um casal. De forte apelo sensorial, o poema faz alusão à beleza das formas da Chica, bem como ao seu cheiro - intimidade -, à cor da pele e ao brilho do sorriso da amada. Sendo o madrigal uma categoria de canção, a expressão "oh Chica" faz as vezes de refrão, constituindo-se como uma interjeição denotativa da paixão que Fernandes nutria por Chica da Silva. O eu lírico de Torres alterna-se entre a voz narrativa que narra o feito de outrem, e por vezes empresta voz à personagens dos poemas, através de ênfase na primeira pessoa do singular, colocando-se como sujeito dos acontecimentos narrados.

O estilo sintético de Torres atinge seu ápice no minimalismo deste poema de apenas um verso:

Tuas águas - apagadas!*

No pé da página, a chave para a leitura do poema: “*Diamantina. Os rios da cidade de Diamantina, filtrados de pedras e pepitas, têm seu brilho apagado pela exploração mineral." O poema prescinde de explicação na medida em que a nota não deve ser tomada como nota de rodapé, mas sim como parte constitutiva do poema, numa relação de complementaridade entre 
o verso e a informação brevíssima contida no asterisco. Trata-se de um poema mínimo, que, com extrema economia e destreza na disposição dos vocábulos, expressa muito.

Milton Torres prossegue em sua jornada poética pela historiografia brasileira cantando a independência do Brasil com Dom Pedro I, a cultura e erudição de um Dom Pedro II cujo simulacro lírico expõe a crítica atemporal "deste inculto malsão e desigual Brasil" (p.153); o ciclo do café. Ainda no século XIX, o empreendorismo de um Barão de Mauá que aprendeu e aplicou a industrialização inglesa: "um gaúcho pensa inglês, mas vive da banda de cá" (p.160); o ciclo da borracha que põe a nu explicitamente a questão do tempo: "as veias de fora - como a espinha do peixe -,/escorre o látex/pinga o tempo sem fim” (p.162). O látex que pinga o tempo dialoga com um poema posterior do livro, na clepsidra que por sua vez "vaza gota a gota, supérfluo relógio/deste Tempo - que desanda” (p.171).

A permanente constatação da inexorabilidade do tempo - que enquanto flui também aprisiona o homem em uma contraditória permanência ontológica no presente - funde-se com a noção da condição trágica do sujeito pós-moderno, o qual busca alguma unidade que o liberte de sua célula de fragmentação peremptória. A criação poética permite que o sujeito vá além da existência ordinária e torne-se ele mesmo demiurgo, constituindo-se a si mesmo no eterno devir da existência:

El hombre es lo inacabado, aunque sea cabal em su misma inconclusión; y por eso hace poemas, imágenes em las que se realiza y se acaba sin acabarse del todo nunca. Él mismo es un poema: Es el ser siempre em perpetua posibilidad de ser completamente y cumpliéndose así en su no-acabamiento. Pero nuestra situación histórica se caracteriza por el demasiado tarde y el muy pronto. Demasiado tarde: en la luz indecisa, los dioses ya desaparecidos, hundidos sus cuerpos radiantes em el horizonte que devora todas las mitologías pasadas; muy pronto: el ser, la experiencia central saliendo de nosotros mismos hacia el encuentro de su verdadera presencia. Andamos perdidos entre las cosas, nuestros pensamientos son circulares y percibimos apenas que algo emerge, sin nombre todavía.(PAZ, p.268)

Depois do século XIX, Torres atravessa a proclamação da república e nos conduz até o século XX. A partir daí o eu lírico se debruça por vários poemas sobre a ditadura militar brasileira, situando o leitor em uma data quase precisa, "quase" porque nebulosa como os acontecimentos trágicos perpetrados pela máquina da repressão, quando o medo termina por emudecer o protagonismo do eu lírico:

$$
\text { BRASIL }-70
$$


a medo vivo, a medo escrevo e falo, hei medo do que falo só comigo,

mas inda a medo cuido, a medo calo.*

Mais uma vez, o poema traz um complemento no rodapé, onde se encontra a referência ao poeta da Renascença: *Sá de Miranda.

Neste ponto da obra o referencial histórico dilui-se e a poesia de Torres torna-se cada vez mais hermética. Chegamos à década de 80, e o mundo muda depressa demais. Torres abraça o desafio de cantar um tempo moribundo de valores e esperanças e menciona o mercado de trabalho; o sonho da revolução do proletariado enterrado sob a supremacia hegemônica do capitalismo; a queda do muro de Berlim. O poeta então canta o homem sertanejo que arranca por teimosia a sobrevivência da lama, do mar, da terra seca. O homem torna-se vegetal e entre o mangue, as águas e o deserto confunde-se com a caatinga (p.191):

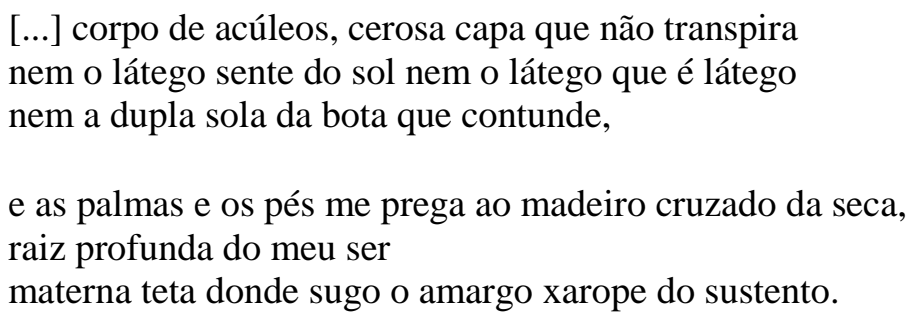

Tanto Fernando Pinto do Amaral quanto Milton Torres são bardos de uma era que conhece seu término. Entretanto, a história, como a arte, é contínua. A poesia se dá no tempo, mas a obra é persiste tanto no momento da criação quanto no da fruição. Expressa o desejo e a necessidade de se buscar na alteridade a unidade perdida na desagregação do sujeito moderno. $\mathrm{Na}$ era da informação, o mundo se tornou menor, porém o estilhaçamento é a marca mais incisiva deste tempo em que, para nos reconhecermos como semelhantes, a constatação e afirmação da diferença tornam-se quase questões de histeria coletiva. Em um começo de século que se afoga na própria sede de novos paradigmas sociais e culturais, Amaral e Torres cantam uma melancolia que entretanto quer conhecer a ocorrência de um futuro jubiloso, o qual só se torna possível mediante a poiesis. 


\section{REFERÊNCIAS}

AMARAL, Fernando Pinto do. Dez elegias para o fim do milênio. In:_. Poesia reunida. Lisboa: Dom Quixote, 2000.

HEGEL, G. W. F. Curso de estética: o sistema das artes. São Paulo: Martins Fontes, 1997.

PAZ, Octavio. O arco e a lira. Rio de Janeiro: Nova Fronteira, 1982.

TORRES, Milton. No fim das terras. Cotia, SP: Ateliê Editorial, 2004. 